\title{
ELECTRO-ACUPUNCTURE MODIFICATION OF HALOTHANE ANAESTHESIA IN THE DOG
}

\author{
Chin-Kai Tseng, Aye-Aye L. Tay, Nathan L. Pace, Dwayne R. Westenskow and K.C. Wong
}

\begin{abstract}
The effects of electro-acupuncture on minimum alveolar anaesthetic concentration (MAC) was studied during halothane anaesthesia in the dog. Following induction of anaesthesia, MAC was determined in duplicate. Ten dogs then received electro-acupuncture bilaterally at San Yin Chiao for 30 minutes. MAC was determined in duplicate while electro-acupuncture was continued. Electro-acupuncture significantly lowered MAC from 1.2 per cent to 1.0 per cent $(p<0.01)$. A crossover experimental design was used in an additional eleven dogs. Here MAC was lowered from 1.17 per cent to 1.04 per cent $(p<0.05)$. Electro-acupuncture produces a small but statistically significant reduction in halothane MAC.
\end{abstract}

KEY WORDS: ACUPUNCTURE, modification of minimum anaesthetic concentration, (MAC); ANAESTHETICS, volatile, halothane.

\begin{abstract}
ACUPUNCTURE HAS BEEN PRACTICED in China for thousands of years for both its therapeutic and analgesic properties. ${ }^{1}$ More recently, Chinese physicians have claimed that acupuncture can create an analgesic state sufficient for surgery. ${ }^{1}$ Acupuncture was reintroduced to western medicine about 1972. Since then its analgesic effect has been studied in man and animal. Initial Western clincial reports showed acupuncture analgesia to be inconsistent and inadequate by itself for surgery. ${ }^{2-4}$ In human experimental pain studies, acupuncture and electro-acupuncture have elicited a more consistent analgesic effect. ${ }^{5}$

We postulated that if electro-acupuncture produced analgesia this should be reflected in a reduction in anaesthetic requirements for known anaesthetic drugs. Therefore, we sought changes in halothane minimum alveolar anaesthetic concentration (MAC) produced by electroacupuncture in the dog.
\end{abstract}

Chin-Kai Tseng, M.D., Visiting Professor; Nathan L. Pace, M.D., Associate Professor; Dwayne R. Westenskow, Ph.D., Assistant Professor; K.C. Wong, M.D., Ph.D., Professor and Chairman; Aye-Aye L. Tay, M.D., Research Fellow; Department of Anesthesiology, University of Utah College of Medicine, 50 North Medical Drive, Salt Lake City, Utah 84132.

Presented in part at the annual meeting of the American Society of Anesthesiologists, San Francisco, California, October, 1979.

Address correspondence and reprint requests to Dr. N.L. Pace, Department of Anesthesiology, University of Utah College of Medicine, 50 North Medical Drive, Salt Lake City, Utah 84132.

\section{Methods}

The determination of MAC followed the method of Eger et al. ${ }^{6}$ Mongrel dogs unselected for age and breed and weighing about $10 \mathrm{~kg}(9.7 \pm$ $2.8 \mathrm{~kg}$, mean $\pm \mathrm{SD}$ ) were anaesthetized with halothane in oxygen. The trachea was intubated without muscle relaxants or other drugs with a tightly fitting, cuffed tracheal tube. Anaesthesia was continued and the lungs were ventilated. mechanically. A femoral artery catherter was inserted for arterial blood gas sampling and continuous pressure monitoring. A foreleg vein was cannulated for fluid administration. Rectal temperature was taken with a glass thermometer and temperature was maintained between $36-38^{\circ} \mathrm{C}$ with a heating lamp and blanket. Temperature did not vary more than $1^{\circ} \mathrm{C}$ during the experiment in any dog.

Respiratory gases were aspirated from a catheter inserted down the trachel tube and monitored continuously by an infrared gas analyzer (Beckman LB-2) for halothane; the infrared analyzer was calibrated every two hours against known concentrations of halothane. A given end-tidal anaesthetic concentration was maintained for at least 15 minutes before testing. The stimulus used was a $25 \mathrm{~cm}$ haemostat clamped onto the shaved tail $5-10 \mathrm{~cm}$ from its base until the ratchet caught; the tail was moved continuously with the haemostat for 60 seconds. Gross, purposeful, muscular movements (jerking, twisting, running or clawing) were considered 


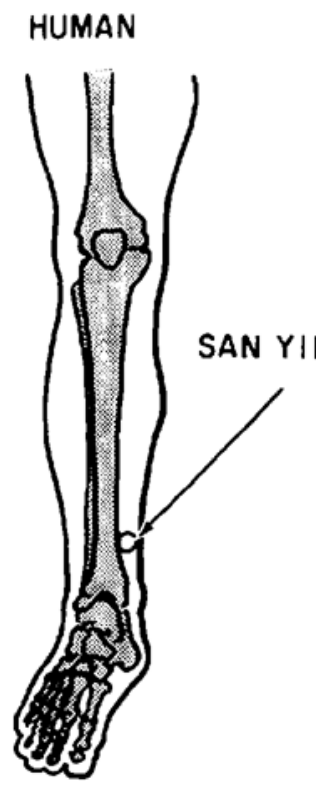

Figure l Acupuncture Locus.

positive responses; coughing, swallowing, chewing, stiffening and hyperventilation were not considered positive responses. ${ }^{6}$ Two observers viewed all responses to stimulation. MAC was taken to be the concentration midway between the highest concentration allowing and the lowest concentration preventing a positive response. MAC was determined in duplicate; the time required for a duplicate determination was about two hours. MAC was expressed as a fractional concentration of one atmosphere.

Electro-acupuncture was done bilaterally at San Yin Chiao (over the medio-posterior aspect of the tibia, one-third of its length from the distal end). San Yin Chiao is the traditional acupuncture point for the caudal region. An equivalent acupuncture locus has been suggested for the dog (Figure 1). Bilateral electro-acupuncture is thought to increase potency. Stainless steel, $6.6 \mathrm{~cm}$ acupuncture needles (Igarashi Ika Kogyo Co., Ltd., Tokyo, Japan) were inserted intramuscularly. The electrical stimulus was a filtered square wave; pulse width was $1 \mathrm{msec}$ at $2 \mathrm{~Hz}$ and $0.7 \mathrm{msec}$ at $200 \mathrm{~Hz}$. Four to six volts maximum amplitude was used and this produced minimal local muscle twitch; current was not measured. The stimulation pattern was a $2 \mathrm{~Hz}$ signal continuously for five minutes, alternating with five minutes of a $200 \mathrm{~Hz}$ signal given for three seconds followed by a onc second rest (Figure 2).

Electro-acupuncture was administered to two

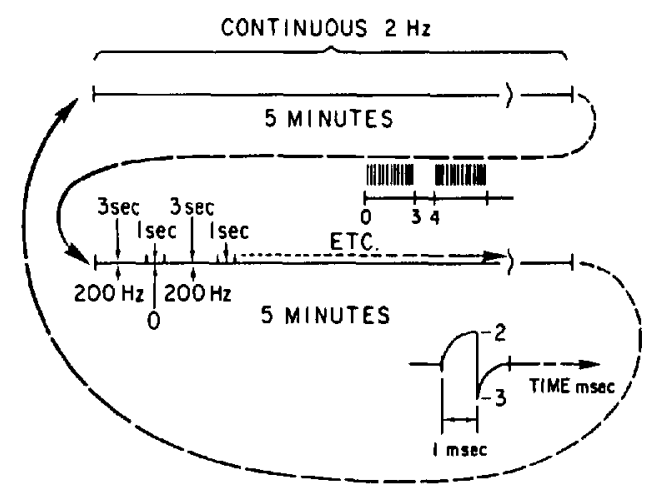

$\mathrm{I}$ = STIMULUS-FILTERED SQUARE WAVE

$2=$ PULSE WIDTH-I msec AT $2 \mathrm{~Hz} ; 0.7 \mathrm{msec}$ AT $200 \mathrm{~Hz}$

$3=4-6$ VOLTS MAXIMUM AMPLITUDE; MINIMAL LOCAL MUSCLE TWITCH

FIGURE 2 Electro-acupuncture stimulation pattern.

groups of animals. In group I (ten dogs) a control determination of MAC was made. Electroacupuncture was then initiated. Thirty minutes later a redetermination of $\mathrm{MAC}$ was started. Acupuncture was continued throughout.

Although halothane MAC in dogs has been shown not to vary with time during prolonged anaesthesia, ${ }^{6}$ a second group of animals received electro-acupuncture under a crossover experimental design to eliminate any bias induced by possible changes with time. Group II animals (11 dogs) were anaesthetized twice. Each dog was studied during two separate study sessions two days apart. Five dogs had a control MAC determined during the first study session; two days later MAC during electro-acupuncture was obtained. In six dogs the reverse order was used.

\section{RESULTS}

Electro-acupuncture produced a statistically significant decrease in halothane MAC in both groups I and II (Table I). In group I, the control MAC was $1.20 \pm 0.08$ per cent which fell to $1.00 \pm 0.06$ per cent (mean \pm SEM) during acupuncture. In group II, the MAC dropped from $1.17 \pm 0.06$ per cent to $1.04 \pm 0.04$ per cent (mean $\pm \mathrm{SEM}$ ).

A comparison of mean blood pressure and heart rate before and during acupuncture showed no differences (Tables II and III). This was true for both groups I and II. This comparison of blood pressure and heart rate was made between values obtained immediately before tail stimulation at the lowest anaesthetic concentration allowing movement. 
TABLE 1

Effect of Electro-Acupuncture on Halothane Mac

\begin{tabular}{|c|c|c|}
\hline & Control & Acupuncture \\
\hline Group I (10 animals) & 1.20 per cent \pm 0.08 per cent & 1.00 per cent \pm 0.06 per cent \\
\hline \multicolumn{3}{|c|}{$\begin{array}{l}t=4.34 ; p<0.01 \\
(d f=9 ; \text { two tail paired } t \text {-test })\end{array}$} \\
\hline Group II (11 animals) & 1.17 per cent \pm 0.06 per cent & 1.04 per cent \pm 0.04 per cent \\
\hline \multicolumn{3}{|c|}{$\begin{array}{l}t=2.62 ; p<0.05 \\
(d f=10 ; \text { two tail paired t-test })\end{array}$} \\
\hline
\end{tabular}

[Per cent Atm: Mean \pm SEM]

TABLE II

Effect of Electro-Acupuncture on Mean Blood Pressure

\begin{tabular}{lcc}
\hline \hline & Control & Acupuncture \\
\hline $\begin{array}{l}\text { Group I (10 animals) } \\
\mathrm{t}=0.28 ; p>0.8\end{array}$ & $100 \pm 10$ & $95 \pm 11$ \\
$(\mathrm{df}=9 ;$ two tail paired $\mathrm{t}$-test $)$ & & \\
Group II ( 11 animals) & $97 \pm 7$ & $95 \pm 5$ \\
$\mathrm{t}=0.30 ; p>0.8$ & & \\
(df $=10 ;$ two tail paired $t$-test) & & \\
\hline
\end{tabular}

[Torr: Mean \pm SEM]

TABLE III

Effect of Electro-Acupuncture on Heart Rate

\begin{tabular}{lcc}
\hline \hline & Control & Acupuncture \\
\hline Group I $(10$ animals $)$ & $101 \pm 5$ & $107 \pm 7$ \\
$\mathrm{t}=0.83 ; \mathrm{p}>0.4$ & \\
$(\mathrm{df}=9 ;$ two tail paired t-test $)$ & & \\
Group II ( 11 animals) & $102 \pm 8$ & $101 \pm 6$ \\
$t=0.16 ; p>0.8$ & & \\
(df $=10 ;$ two tail paired $t$-test $)$ & & \\
\hline
\end{tabular}

[Beats per Minute: Mean \pm SEM]

\section{Discussion}

Following visits to China by western anaesthetists in the early 1970 s, several attempts to use acupuncture or electro-acupuncture were reported. Mann attempted to provide analgesia for unspecified types of operations using acupuncture in 35 subjects; ${ }^{2}$ in only 10 per cent were results adequate. Wallis and colleagues also studied acupuncture as a method for relief of pain during labour and delivery in 31 parturients. ${ }^{3}$
Analgesia was inadequate in 19. In another series, eight patients undergoing superficial plastic surgery were given electro-acupuncture as an alternative to local analgesia, but in four of the eight analgesia was so inadequate that the operation had to be completed using local analgesia. ${ }^{4}$ These reports concluded that acupuncture by itself is inadequate to provide surgical anaesthesia.

Acupuncture and electro-acupuncture have also been studied for relief of experimentallyinduced pain in unanaesthetized men and ani- 
mals. Reichmanis and Becker ${ }^{5}$ recently reviewed 24 studies in man. Significant analgesia effects were reported in 17 studies; negative or equivocal results were reported in the other seven. Several studies have also shown that electro-acupuncture analgesia is possible in mice and rabbits. ${ }^{7-9}$

Other investigators have shown that electroacupuncture is associated with vascular depression in the dog during halothane anaesthesia. ${ }^{10.11}$ Contrary to our results, however, Stoelting and co-workers $^{12}$ in 1973 reported no change in halothane $\mathrm{MAC}$ in the dog by electroacupuncture.

The negative results of Mann, ${ }^{2}$ Wallis, ${ }^{3}$ Modell, ${ }^{4}$ and Stoelting ${ }^{12}$ appear to have discouraged further clinical study of acupuncture in the operating room. However, several reports from Germany in which electro-acupuncture has been used as an adjuvant method during general anaesthesia claim good circulatory stability and lower anaesthetic requirements. ${ }^{13-16}$ Our study clearly showed reduction in halothane MAC in the dog by electro-acupuncture. Our results might encourage the study of utilizing acupuncture together with chemical anaesthesia. Whether the extra time and equipment required would produce superior anaesthetic results would have to be proven. However, the relatively small reduction in MAC suggests that electroacupuncutre will have little clinical significance in surgical anaesthesia.

\section{REFERENCES}

1. BOWERS, J.Z. Reception of acupuncture in the scientific community: From scorn to a degree of interest. Comp. Med. East. West. 6: 89-96 (1978).

2. MANN, F. Acupuncture analgesia: Report of 100 experiments. Brit. J. Anaesth. 46: 361-364 (1974).

3. Wallis, L., Shinder, S.M., PalahniUk, R.J. \& SPIVELY, H.T. An evaluation of acupuncture analgesia in obstetrics. Anesthesiology 41:596-610 (1974).
4. Modell, J.H., LeE, P.K., Bingham, H.G., Greer, D.M. \& HABEL, M.B. 'Acupunctureanesthesia' -A clinical study. Anesth. Analg. 55: 508-512 (1976).

5. Reichmanis, M. \& Becker, R.O. Relief of experimentally-induced pain by stimulation at acupuncture loci: A review. Comp. Med. East. West. S: 281-288 (1977).

6. Eger, E.I.II, Saidman L.J. \& Brandstater, B. Minimum alveolar anesthetic concentration. A standard of anesthetic potency. A nesthesiology 26: 756-763 (1965).

7. Pomeranz, B. \& Chiu, D. Naloxone blockade of acupuncture analgesia. Endorphin implicated. Life Sci. 19: 1757-1762 (1976).

8. MCLennan, H., Gilfillan, K. \& Heap, Y. Some pharmacological observations on the analgesia induced by acupuncture in rabbits. Pain 3: 229-238 (1977).

9. Galeano, C., Leung, C.Y., Robitaille, R. \& Roy-Chabot, $T$. Acupuncture analgesia in rabbits. Pain 6: 71-81 (1979).

10. Lee, M.O., LeE, D.C., Kim, S. \& Clifford, D. H. Cardiovascular effects of acupuncture at Tsu San $\mathrm{Li}$ (St-36) in dogs. J. Surg. Res. 18: 51-63 (1975).

11. Clifford, D.H., Lee, M.O. \& LeE, D.C. Cardiovascular effects of atropine on acupuncture, needling with electro-stimulation, at Tsu San $\mathbf{L i}$ (St-36) in dogs. J.A.V.M.A. 38: 845-849 (1977).

12. Stoelting, R.K., Kim, K.C., Peterson, C. \& HASELBY, K.A. The influence of acupuncture on halothane MAC in dogs. Anesthesiology 39: 661 (1973).

13. SChaer, H. On the quantification of the analgesicanesthetic effect of electrostimulation. Anacsthesist 28: 52-59 (1979).

14. Hollinger, I., Richter, J.A., Pongratz, W. \& BAUM, M. Acupuncture anesthesia for open heart surgery: A report of 800 cases. Am. J. Chin. Med. 7: 77-90 (1979).

15. Abdulla, W., Sostegno, C., Frey, R. \& GärtNER, J. The circulatory system in patients under electrostimulation anaesthesia during ophthamological operations. Anaesthesist 28 : 221-226 (1979).

16. Baum, J. \& Schilling. A. Combined electrostimulation-hypalgesia in surgery of the lumbar vertebral columm. A tentative evaluation of this method. Anaesthesist 28: 227-236 (1979).

\section{RÉSUMÉ}

On a étuidé chez le chien l'influence de l'électro-acupuncture sur la concentration alvéolaire minimale (MAC) de l'halothane. A cette fin, deux mesures de MAC en halothane ont été effectuées chez chaque animal après l'induction. Dix chiens ont ensuite reçu 30 minutes d'électro-acupuncture au point de San Hin Chiao (un des points traditionnels sur le tibia). La mesure de MAC était alors répétée tout en continuant l'électro-acupuncture. La MAC en halothane était abaissée de façon significative par l'électro-acupuncture, passant de 1.2 à 1 pour cent $(\mathrm{p}<0.01)$.

Onze autres animaux (groupe II) ont été anesthésiés à deux reprises, soit à deux jours d'intervalle. La mesure de MAC était établie lors de la première séance et à nouveau sous électro-acupuncture lors de la seconde. L'ordre a été inversé chez six des chiens du groupe II. A nouveau, on a trouvé que la MAC était abaissée sous électro-acupuncture (1.04 vs 1.17 -p < 0.05).

L'électro-acupuncture diminue donc de façon légère mais significative la concentration anesthésique alévolaire minimale (MAC) en halothane. 